\title{
Dollarisation and the Underground Economy: Accidental Partners?
}

Šošić, Vedran; Faulend, Michael

Source / Izvornik: Occasional Paper Series, 2002, 6, 1 - 22

Journal article, Published version

Rad u časopisu, Objavljena verzija rada (izdavačev PDF)

https://doi.org/10.3326/ops.15

Permanent link / Trajna poveznica: https:/urn.nsk.hr/urn:nbn:hr:242:285212

Rights / Prava: Attribution-NonCommercial-NoDerivatives 4.0 International/ImenovanjeNekomercijalno-Bez prerada 4.0 međunarodna

Download date / Datum preuzimanja: 2023-04-26

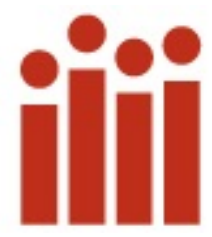

Institute of Public Finance Repository

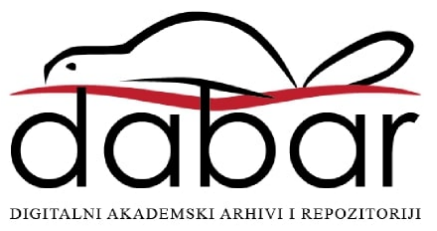




\title{
DOLLARISATION AND THE UNDERGROUND
} ECONOMY: ACCIDENTAL PARTNERS?

\author{
Vedran Šošić \\ Michael Faulend
}

Occasional Paper No. 15

April 2002 


\title{
DOLLARISATION AND THE UNDERGROUND ECONOMY: ACCIDENTAL PARTNERS?
}

\author{
Vedran ŠOŠIĆ ${ }^{1}$ \\ Croatian National Bank, Zagreb \\ Michael FAULEND \\ IMF, Washington
}

\begin{abstract}
Monetary methods of measuring the underground economy (UE) in all their variations are traditionally based upon domestic monetary aggregates. In recent times, however, there has been an increasing amount of evidence supporting the thesis that it is actually foreign currency that is very often linked with the UE in countries in which the phenomenon of dollarisation is widespread. New understanding of the extent and dynamics of dollarisation can, then, provide important information about the dynamics of the UE in these countries.

Results derived from estimates of the amount of foreign cash in circulation in Croatia, in our estimation, show a rising tendency in the UE, like traditional monetary methods, which in principle does not have to be the case. Similar tendencies in the UE are indicated by the dynamics of electricity consumption.
\end{abstract}

JEL Classification: O17, E59

Key words: underground economy, dollarisation

\footnotetext{
${ }^{1}$ The views of the authors expressed in this work are not necessarily those of the institutions in which they work, nor do they oblige these institutions in any way.
} 


\section{DOLLARISATION AND THE UNDERGROUND ECONOMY: ACCIDENTAL PARTNERS?*}

\section{Introduction}

Monetary methods of estimating the UE have been applied in a lot of countries during the last four decades because they are relatively simple to employ and they show the dynamics of the UE over a longer period of time with, as is usually thought, a reasonable degree of reliability, considering the nature of the phenomenon under observation. At the same time, these methods have been subject to serious criticisms because of the rigid and arbitrary assumptions on which they are based (Jankov, 1997). In addition, monetary methods do not give independent estimates of the absolute level of the UE, but can only be used for an estimate of its dynamics, and start from the assumption that the UE did not exist at some given period taken as the point of departure, and the absolute level is obtained by accumulation. Alternatively, it is necessary to take for the initial period some estimate obtained by one of the alternative methods through which it is possible to determine the absolute size of the UE.

In our opinion, the very wide spread of dollarisation in many developing countries and the use of foreign cash in the UE are a much greater obstacle in the way of the reliability of these methods than the reliance on assumptions that are not empirically confirmed. For example, the substitution of the local currency for some foreign currency that is indicated as being used in the UE can actually imply a reduction in the UE, and not an expansion of it, as would be suggested by monetary methods of assessing the UE based upon the demand for domestic cash.

In line with this viewpoint, the basic purpose of this paper is to use estimates of the amount of foreign cash in circulation in Croatia for an evaluation of UE tendencies. Taking into account the existing great uncertainty about the estimate of the amount of foreign cash in circulation, and the link between dollarisation and the UE, our estimate will be of an indicative nature.

We shall begin the paper with a consideration of the definitions of dollarisation and currency substitution and their basic indicators that will be used in the continuation of the paper. We go on with a consideration of the links between the UE and dollarisation that are known in the literature. After this part, which is more theoretical in nature, we go on with empirical estimates of the amount of foreign cash in circulation in Croatia. After a brief look at traditional methods of measuring the UE and their shortcomings in the light of empirical knowledge about dollarisation, we use estimates of the amount of foreign currency in circulation to draw conclusions about UE dynamics. At the end, we compare our estimates, based on monetary methods, with results derived from the electricity consumption measurement method.

\section{The concept and the measurement of dollarisation}

There is no consensus in economic literature about the concepts of currency substitution and dollarisation. Different authors have frequently employed them as synonyms, but each of the concepts has also been used to denote diverse phenomena. The problem we have with the definition of dollarisation and currency substitution derives from the large number of functions that money has in any economy. Thus these concepts are used to indicate the replacement of the domestic money by foreign money in any of its traditional roles, the substitutability of domestic securities with foreign securities, and even the dependence of demand for domestic money on foreign economic variables. ${ }^{2}$ These have been endeavours to

\footnotetext{
* This article is published in Croatia in the journal "Financijska teorija i praksa", 26 (1), 2002., pp. $57-$ 83, available at http://www.ijf.hr/financijska praksa/PDF-2002/sosic\&faulend.pdf.
} 
encompass the diversity of the phenomenal forms of foreign money, such as cross-border deposits, the depositing of foreign money inside the country, and the circulation of foreign cash in the country.

Feige, Faulend, Šonje and Šošić $(2001)^{3}$ consider unofficial dollarisation to be the use of a foreign currency as money in the domestic economy. From this definition derives an index of unofficial dollarisation that is its broadest measure, and is defined as the share of foreign money, in whatever phenomenal form, in the effective broad money supply, or as the ratio of the sum of foreign cash and foreign currency deposits and the effective broad money supply in the country ${ }^{4}$. This can be stated by the identity:

$$
\mathrm{UDI} \equiv(\mathrm{FCC}+\mathrm{FCD}) / \mathrm{EBM} .
$$

where UDI is the unofficial dollarisation index, FCC is the foreign currency in circulation, and FCD is the foreign currency deposits. As can be seen from identity (1a), the broadly defined money supply is the sum of local cash in circulation (LCC), foreign cash in circulation (FCC), local checkable deposits (LCD) and quasi-money (QM), or the broadly defined money supply (BM) increased by the foreign cash in circulation:

$$
\mathrm{EBM} \equiv \mathrm{LCC}+\mathrm{FCC}+\mathrm{LCD}+\mathrm{QM} \equiv \mathrm{BM}+\mathrm{FCC}
$$

Currency substitution, as a narrow measure of dollarisation, is defined in the work quoted as the use of a foreign currency in the role of the unit of account and as a means of payment. In line with this, the currency substitution index denotes the share of the foreign currency component in the cash as a whole:

$$
\mathrm{CSI} \equiv \mathrm{FCC} /(\mathrm{FCC}+\mathrm{LCC})
$$

where CSI is the currency substitution index, and LCC is the local cash in circulation. Since apart from local cash, deposits in current and giro accounts are also used as a means of payment, it is useful to define a modified currency substitution index to take into account the share of foreign cash in the effective narrow money supply. The identity for the modified currency substitution index is

$$
\mathrm{CSIn} \equiv \mathrm{FCC} / \mathrm{ENM}
$$

where CSIn is the modified currency substitution index, and ENM is the narrow money supply, or, as we have shown in identity (3a), the narrow money supply (NM) augmented by the foreign cash in circulation.

$$
\mathrm{ENM} \equiv \mathrm{NM}+\mathrm{FCC} .
$$

Dollarisation is a complex phenomenon, and the ideal measurement of it should be able to take into the account all prices and financial instruments denominated in a foreign currency, which is very difficult indeed. From the definition of currency substitution and dollarisation it can be seen that the foreign cash in circulation is the main component of currency substitution and an important, sometimes determining, component of dollarisation. Since the phenomenon of the UE is often linked to the cash in circulation, it is clear that in dollarised countries the UE will be connected precisely with the concept of currency substitution. For this reason in

\footnotetext{
${ }^{2}$ Giovannini and Turtelboom (1992) discuss the diversity of definitions in detail.

${ }^{3}$ We use the phrase unofficial dollarisation to stress the difference from the official acceptance of a foreign currency as a means of payment. In the rest of the work by dollarisation we mean its unofficial version.

${ }^{4}$ Effective money supply is defined as the sum of the appropriate monetary aggregate (broad or narrow money) and foreign cash circulating in the country.
} 
this brief summary of the various ways of measuring dollarisation we have concentrated on a measurement of currency substitution that is based on the foreign cash in circulation.

It is possible to distinguish two groups of methods for measuring the amount of foreign currency in circulation. The first group encompasses direct methods of measurement. Statistical monitoring of the inflows and outflows of domestic cash (from the standpoint of the issuing country) or of foreign currency at the moment it crosses the border is the basic direct method. In open countries with high foreign currency inflows (high with respect to GDP) from tourism and transfers from expatriates (which because of geographical propinquity often arrive in the form of cash) such as Croatia, it is often very difficult to record these inflows. Survey on the amount of foreign cash held by the population is the second direct method, through which it is possible to avoid the shortcomings of statistical reporting about cash flows. However, the results obtained by this method are also very unreliable as they have two essential failings: on the whole, people are unwilling to give out their own financial details, and it is very difficult to define a representative sample of respondents. There will be further discussion of direct methods of measuring dollarisation and problems with the results of statistical records of cash flows in the discussion of dollarisation in Croatia.

Because of all these shortcomings of the direct methods, a number of indirect methods have been developed, which also allow for an estimation of the amount of foreign cash in circulation. The simplest indirect method for calculation of the level of dollarisation uses the dynamics of the share of foreign currency deposits in the broadly defined money supply in order to draw conclusions about the trends in the level of overall dollarisation. However, foreign currency deposits are often substitutes for foreign cash and cross-border deposits, and not complement as this method assumes. There are also numerous other indirect methods that include international comparisons of per capita cash holdings, econometric modelling of money demand, method of maximum likelihood of money demand function, comparison of denomination structures of domestic cash, etc. All of these methods are also partial in their nature, but unlike foreign currency deposits method, they focus on foreign currency in circulation.

\section{Dollarisation and the underground economy}

The connection between the UE and dollarisation is well known in the literature (a summary of knowledge about the demand for foreign currency stemming from the UE is given in: Rogoff, 1998). Both these areas, however, are shot through with uncertainties and unknowns, and for the moment it would seem that to derive any kind of empirical links between the two phenomena belongs more to the sphere of speculation than that of science.

A continued fall in the value of the local currency over a long period of time and a complex of various institutional circumstances are the causes most commonly cited for dollarisation. Institutional factors include the confiscation of deposits or the loss of them because of frequent and expensive banking crises in dollarised countries, and the limited convertibility of the local currency combined with vigorous involvement in international trade. The unofficial economy is not often cited as a direct cause of dollarisation. However, widespread dollarisation, which we shall discuss below, certainly makes working in the UE a great deal easier. It is known that the UE is one of the known major reasons for the demand for cash in developed countries. Although no precise quantification exists, some authors argue that it is very probable that some of the central banks in developed OECD countries make most of their seigniorage on the cash that is used in the UE (Rogoff, 2000). In countries outside the group of developed countries, in which the problem of the UE is much more pronounced, the UE is also one of the great wellsprings of the demand for the stable currencies of OECD countries.

Taxation and various administrative regulations, as well as the wide spread of corruption and discretionary decision-making in the administration are most frequently adduced as determining factors in the UE. These variables represent gains from engaging into the UE, or 
by avoiding the burdens of doing business in the OE. Withal, getting into the UE involves the burden of loss of access to certain public goods, mainly the judiciary, and then there are the potential costs in the event of detection by the state. If the potential benefits of the protection of claims and other forms of property by the government agencies are not perceived as being very great, the opportunity costs of getting involved in the UE are lower.

Some authors have been inclined to take the view that apart from positive effects in the form of providing a stable support in an environment in which assets denominated in the local currency are exposed to losses, the existence of a parallel, stable monetary unit, can well make doing business in the UE in such countries much easier (Feige et al., 2001 and Rogoff, 1998). Institutional shortcomings that lead to macroeconomic instabilities can also be a stimulus to working in the UE (Kaufmann and Kaliberda, 1996). To the extent to which the mere use of foreign cash in transactions is deemed an offence, advanced dollarisation can be a considerable stimulus to the concealment of economic activities.

Apart from reducing transaction costs, the use of a foreign currency, like that of cash in general, is connected to certain other advantages of doing business in the UE. Cash leaves no paper trails and enables its users to retain their anonymity. Of course, if foreign cash were used entirely by persons who are involved in the UE in some way, their anonymity would be lost. Anonymity is enabled precisely by the fact that foreign currency is a common phenomenon with other people too, people who are not involved in any illegal actions or in the UE. In addition, cash is not the only transaction means in the UE, and the authorities in many countries wage a battle with persons who use various financial techniques to legalise profits made in the $\mathrm{UE}^{5}$ or to introduce it into the financial system. Furthermore, there are indications in transition countries that exceptionally high level of non-monetary transactions, according to the criteria of developed market economies, is also linked with the flourishing of the UE. Some authors argue that volume of non-monetary transactions in transition countries grew particularly because of the possibilities for distorting the picture of financial flows and for concealing profit (Gaddy and Ickes, 1998). These facts however do not undermine the thesis that foreign cash is dominantly used as a main vehicle for the UE of the transition countries, even when findings indicate that the UE is widespread in relatively large firms the main activities of which are oriented to the $\mathrm{OE}$, which is a specific feature of the transition countries.

As well as the theoretical assumptions, there is certain empirical evidence about the importance of foreign cash in the UEs of dollarised countries. First of all, questionnaires about the use of cash in some OECD countries in general manage to identify only a small part of the cash that are known to be in circulation, according to reliable data from the balance sheet of the central bank. Table 1 gives data about the amount of cash in circulation in some industrial countries and in Croatia.

\footnotetext{
${ }^{5}$ A detailed account of various ways of misusing the financial system and the fight against them is given in IMF (2001).
} 
Table 1 Amount of cash in circulation in some industrial countries and in Croatia (in USD per capita)

\begin{tabular}{|c|c|c|c|}
\hline & 1998. & 1999. & 2000. \\
\hline Croatia & 200 & 187 & 179 \\
\hline Australia & 764 & 837 & 813 \\
\hline Austria & & 1812 & 1618 \\
\hline Belgium & 1365 & 1422 & 1233 \\
\hline Denmark & 971 & 993 & 873 \\
\hline Finland & 643 & 690 & 592 \\
\hline France & 826 & 888 & 764 \\
\hline Greece & 810 & 971 & 789 \\
\hline Iceland & 330 & & \\
\hline Ireland & 1170 & 1377 & 1301 \\
\hline Italy & 1249 & 1337 & 1233 \\
\hline Japan & 3282 & 4122 & 4543 \\
\hline Canada & 720 & 855 & 796 \\
\hline Luxembourg & & 1449 & 1416 \\
\hline Netherlands & 1312 & 1279 & 1085 \\
\hline New Zealand & 243 & 289 & 245 \\
\hline Norway & 1261 & 1255 & 1091 \\
\hline Germany & 1878 & 1924 & 1594 \\
\hline Portugal & 514 & 775 & 605 \\
\hline Spain & 1434 & 1658 & 1396 \\
\hline Sweden & 1061 & 1074 & 1097 \\
\hline Switzerland & 3437 & 3682 & 3129 \\
\hline UK & 540 & 584 & 609 \\
\hline USA & 1749 & 2079 & 1990 \\
\hline Euro zone & & 1412 & 1210 \\
\hline
\end{tabular}

Source: IMF IFS CD-ROM, August 2001.

Obviously, the amount of cash that some of the central banks have put into circulation considerably exceeds the transaction requirements of their economies, even if one takes into account the demand for cash generated by the UE of these countries. Leaders in the amount of cash per capita are the Japanese, with a sum of about 4,500 USD. It would seem, however, that the relatively high level of cash is largely the result of internal factors, above all the low interest rates and deflation, combined with very low rates of crime and safe streets, and preferences for liquidity rather than to external demand for the yen. To this one should add the high prices in Japan, which also makes some contribution to the demand for cash. Japan is followed by Switzerland, in which the cash in circulation is at the level of 3,000 USD per capita. In fact, according to anecdotal evidence, a considerable amount of francs are in circulation outside Switzerland, but their global role is negligible because of the small size of the country itself. It is also speculated that the large demand for cash in Switzerland is related to the phenomenon of banking secrecy and safe deposit boxes, of which this country is the last refuge in Europe. After Switzerland come the USA and Germany, with an amount of cash that ranges at the level of about 2,000 USD per capita, or about 8,000 USD per four-member family. It can be seen that there was a fall in the amount of German marks in circulation in 2000. This fall can be probably explained by the weakness of the exchange rate of the mark against the dollar and the introduction of euro notes, which led to the return of mark banknotes to Germany and to the banking system on the eve of cash conversion, because of the costs that conversion entailed for persons with a large amount of marks. The amounts of cash in circulation in other industrial countries are much lower, which is in line with the viewpoint that the currencies of these two lands are the main source of foreign cash in circulation outside OECD countries. 
As against this, it can be noticed that the equivalent of cash kuna in circulation during 1999 and 2000 was below 200 USD per capita. While Croatian per capita GDP comes to about a quarter of that of the per capita GDP of the euro zone, the average Croat holds only a sixth or seventh of the amount of cash that, according to central bank data, is held by the average inhabitant of the euro zone. This kind of ratio is particularly unusual if one takes consideration the far weaker development of non-cash forms of payment in Croatia. The ratio of cash to GDP in other transition countries is mainly lower than the average for the euro zone, because of which candidates for the EU and the EMU will have some benefit from taking part in monetary union (Feist, 2001). The low level of domestic cash in circulation is just one more reason for suspecting the existence of quite large amounts of foreign currency that circulate in Croatia.

The amount of cash in circulation in the USA and Germany led to research of its sector and geographical distribution. A questionnaire about the possession of cash that was carried out by the FED among citizens of the USA revealed the location of only about $5 \%$ of the total cash in circulation (Rogoff, 1998). If estimate of cash owned by firms is added, the figure will still be less than a tenth of all the cash in circulation. A part of the shortfall can certainly be ascribed to the usual bias of such questionnaires, but this does not change the fact that the central banks do not know where the major part of cash in circulation lies, that is, how much is in the country and how much is abroad.

There is a wide diapason of estimates about how much cash exists outside the USA. According to the lower estimates, during the 90 s there was only $35-40 \%$ of cash outside the country (Feige, 1996), while at the upper level there are estimates of $60-80 \%$ (Porter and Judson, 1996 and Sprenkle, 1993). These estimates are mainly obtained by indirect methods, but there are also certain direct measurements from which something can be concluded about the geographical distribution of this cash. There is only one relevant study for Germany, but it employs a range of different methods. Since various methods are used, the results also show a wide degree of variation - ranging between 30 and $60 \%$ of the total amount of cash in circulation (Seitz, 1996).

Apart from indirect indications at the macro level about large quantities of banknotes in some OECD countries that are used in the UEs of these countries and of other countries, in which the phenomenon of dollarisation is quite widespread, there is a certain amount of evidence about the importance of dollarisation for the UE at the micro level. Kaufmann and Kaliberda (1996) give information about the importance of foreign cash in circulation, stressing, in their discussion of the results of a questionnaire in the Ukraine, that the various restrictions in the sphere of the exchange rate were one of the key causes for the UE in that country.

\section{Unofficial dollarisation in Croatia}

An attempt to measure foreign cash is an ungrateful job because at the back of every result there is an enormous amount of uncertainty to do with the accuracy, and the result is always subject to criticism and rebuttal. However, measurement of foreign cash is at the same time a challenging task that requires both discernment and boldness from a researcher.

The many measurement methods, as we have mentioned above, can be divided into two basic groups - the direct and the indirect. The basic direct method by which it is sometimes possible to measure the quantity of foreign cash in a country is by measuring the flows of foreign cash as they pass the border or enter or leave the banking system. In Croatia, unfortunately, this method cannot be employed. Firstly, customs data are unreliable and essentially underrate even those flows that are recorded by the banking system. However, if we examine the data about the flows of foreign cash between natural persons and banks shown in Table 2, we will notice that during the last few years the commercial banks have usually been in surplus, even if we look only at those flows between banks and domestic 
natural persons ${ }^{6}$. This is a reflection of the fact that tourism and the transfers of expatriates that are on the whole not registered as they enter the country ${ }^{7}$ are the main sources of the inflow of foreign currency into Croatia.

Table 2 Foreign cash flows between natural persons and commercial banks in Croatia (in mil. USD)

\begin{tabular}{|c|c|c|c|c|c|c|}
\hline & \multicolumn{3}{|c|}{ Domestic persons } & \multicolumn{3}{c|}{ Foreign persons } \\
\hline & Inflow & Outflow & \multicolumn{1}{|c|}{ Net } & Inflow & Outflow & Net \\
\hline 1997 & 5,645 & 4,842 & 802 & 704 & 306 & 398 \\
\hline 1998 & 5,471 & 5,144 & 327 & 839 & 202 & 637 \\
\hline 1999 & 4,355 & 4,468 & -113 & 769 & 172 & 597 \\
\hline 2000 & 4,521 & 3,639 & 882 & 697 & 137 & 560 \\
\hline $2001(1-7)$ & 3,071 & 2,435 & 636 & 379 & 80 & 299 \\
\hline
\end{tabular}

In this work, in making an estimate of the amount of foreign cash in Croatia, we shall use a recently developed indirect method $^{8}$ that has already given very interesting results. This is the denomination displacement method, which is based on the observation that in dollarised countries $^{9}$ the local currency, in time, loses certain characteristics of standard money, which the foreign currency starts to assume. That is, studying unofficial dollarisation in Latin America, Calvo and Vegh (1992) arrived at the conclusion that in conditions of hyperinflation, the foreign currency first of all starts to meet the function of measure of value and store of wealth, and only later starts to serve as a means of exchange. The final phase, that is, the phase in which the foreign currency starts to be used in everyday transactions instead of the local currency is called currency substitution, and it is this phase that is essential for the denomination displacement method mentioned above.

From anecdotal evidence it is known that foreign cash (usually the mark) is used in Croatia mainly for "big ticket" transactions, similar experience being possessed by other dollarised countries. Starting off from this knowledge, the idea arose that the foreign currency would much more markedly drive out the high denominations of the local currency, and that there would be a link between the percentage of local currency high denomination banknotes and the level of the already displayed currency substitution index, which is nothing but the share of foreign currency in the total supply of domestic currency.

Identity (3) very clearly shows that the currency substitution index will be greater in a country that has more foreign currency as compared with the domestic money supply. Considering this fact, we can suppose that countries with a higher currency substitution index will have a smaller percentage of domestic high denominations banknotes, because the foreign banknotes will be used primarily for "big ticket" transactions ${ }^{10}$. The question then arises as to how to calculate, on the basis of this, the FCC in Croatia. The first step in the procedure is the calculation of the currency substitution index (CSIn) for the dollarised countries for which we

\footnotetext{
${ }^{6}$ Naturally, the division into foreign and local natural persons is unreliable and need not have too much faith placed in it.

7 According to current legislation, foreign cash may freely be imported, but it is required to report every inflow worth more than 40,000 kuna to a customs official.

8 The denomination displacement method was worked out in the CNB during the stay of E. L. Feige as part of a research project on foreign cash in Croatia.

9 For the sake of precision, it should be emphasised that a dollarised country is meant to mean a country with unofficial dollarisation, which is also the most common case.

10 "Big ticket" or major transactions mean the purchase of cars, real estate and similar durable goods, but also transactions in the UE that might on average be greater in amount than the average transactions in the local currency because use of local non-cash payment instruments drive out cash from the larger transactions that exist in the OE.
} 
do have data concerning the amount of foreign $\operatorname{cash}^{11}$ and then to gather data about the denomination structures of the given local currency. The next step is the adjustment of the denomination structure in the given countries by the appropriate purchasing power parity indices, which will make them mutually comparable. Then it is necessary to define the concept of high denominations and infer its relationship with the already calculated currency substitution indices. This of course implies the econometric testing of the link and considering the significance of the results, in the last step, with the assistance of estimated value parameters and the actual Croatian values, it is possible to assess the currency substitution index in Croatia and its evolution over time. This also gives an assessment of the amount of foreign cash in Croatia.

The whole of this procedure brings certain problems with it, which one has to be aware of when interpreting the results. But before saying something of the problems of the procedure of the estimate itself and before we start the exposition in the order given, we think that it is necessary to draw attention to one other observation that was crucial for making the assumption that there might be a connection between the percentage share of high denominations of the domestic currency and the currency substitution index. This is the observation that in non-dollarised countries (the US, Canada, Germany, Holland and other industrially developed countries), the total value of domestic currency high denomination notes (that for the purpose of this research we defined as denominations with a value of more than 50 USD) considerably exceeded that of lower denomination (50 USD and below) notes. For example, in the USA, $\$ 100$ banknotes (the only denomination greater than 50) accounted for $60 \%$ of the value, while in Germany notes with denominations of more than $\$ 50$ came to $90 \%$ of the value of all banknotes issued. The high percentage of these high value notes seems almost incredible, since they cannot be seen in the common, everyday transactions in these countries. At the same time in dollarised countries, high denomination domestic currency banknotes range at levels of much less than $50 \%$ of the total value, even allowing for adjustment in the purchasing power parity. In Russia, for example, high denomination notes account for only $10 \%$, and in Croatia about $35 \%$ of the value of all the notes issued. There is an example that is even more extreme, however: Romania, in which there is practically no high denomination local currency note. These indicators are certainly a reflection of the fact that some of the banknotes of the USA and Germany, primarily in the form of high denominations, are circulating in dollarised lands. There is one more reason that we consider that the phenomenon of dollarisation can be primarily linked with high denominations, which is the fact that $85 \%$ of the rise in the amount of dollar cash during the last twenty years, that is, during the period in which according to certain information dollarisation grew vigorously, was in the form of 100-dollar bills. The case with Germany is similar. The example of Romania, and partly that of Russia, indicated problems that might appear in the denomination structure. In countries with high inflation it is often possible to see great instability of the denomination structure, the consequence of the devaluation of the national currency because of high inflation. In such situations new notes are often issued that have a high denomination value at the beginning. Since figures about the denomination structure always register the state at the end of the year, clearly it does not always necessarily correspond to the state of affairs at the introduction of the new notes. From this point of view it would be desirable to exclude such countries, or rather, periods of high inflation in given countries, from the analysis. The problem of inflation (and the linked problem of instability in the denomination structure) is connected with the problem of calculating the currency substitution index. From the previously shown identities it is clear that the reliability of the index depends primarily on the reliability of the data about the amount of foreign currency in circulation. These figures are hard to measure and are subject to great margins of error. But there is one additional drawback: the data available to us reveal only the dollar cash in the countries observed. Here

11 This is to do with US customs figures; since the end of the 70s, this office has monitored inflows and outflows of cash dollars to and from individuals and various institutions that exceed the stipulated limit of $\$ 10,000$. More information about these figures, which provide an insight into the geographical distribution of cash dollars, and their shortcomings, can be read in Feige et al., (2001). 
one consoling factor is that the estimated amount of dollars circulating outside the USA far exceeds the estimate of the quantity of marks in circulation outside Germany ${ }^{12}$.

Apart from all these, there is also a problem related to the adjustment of the denomination structures according to purchasing power parity, without which figures about denomination structures would be incomparable. For the very idea of purchasing power parity (PPP) is based on an attempt to adjust the course of the national currency by an amount that would show the real, i.e., comparable purchasing power of an American dollar in various countries. For this kind of reason it is necessary to create a common basket of goods and services for all countries on the basis of which to compare the value of a dollar in given countries. Because of the inevitability that there will be different consumption preferences in individual countries, the standardised basket is bound to cause errors. In order to palliate this problem, for the transition countries we have used the figures available from the Vienna Institute as a source for the PPP index (WIIW, 2001), while for other countries we have used the data of the World Bank (WB-WDI).

Bearing in mind the problems that exist, which without doubt constrain the analysis itself and reduce the credibility of the data, we embarked first of all on gathering and settling the data, and then on econometric analysis. The process of data collection and processing need not be described, nor what has already partially been stated repeated. A total of 46 observations from 15 countries were collected, that is, on average, three per country. But all of this is shown precisely in Table 3. It can be noticed that most of the data were collected for 1995, 1996, 1997 and 1998, which is good to a degree, since these are years when inflation was no longer a problem in most of the countries. Exceptions are Romania and to some extent Russia; however, irrespective of this, we decided to leave them in the sample and include dummy variables for the high inflation periods. It should be recalled that that the existence of high inflation is a problem in that it disturbs getting a true picture of the denomination structure and thus affects the high denomination variable that is included in economic analysis as an independent variable.

Table 3 Data availability according to countries and periods (HiDenom and CSIn)

\begin{tabular}{|l|c|c|c|c|c|c|c|}
\hline & 1992 & 1993 & 1994 & 1995 & 1996 & 1997 & 1998 \\
\hline Armenija & & & & & $\mathrm{x}$ & $\mathrm{x}$ & \\
\hline Bulgaria & & & & & $\mathrm{x}$ & $\mathrm{x}$ & $\mathrm{x}$ \\
\hline Czech R & & & & & & & $\mathrm{x}$ \\
\hline Estonia & & & & $\mathrm{x}$ & $\mathrm{x}$ & $\mathrm{x}$ & $\mathrm{x}$ \\
\hline Israel & & & & $\mathrm{x}$ & $\mathrm{x}$ & $\mathrm{x}$ & $\mathrm{x}$ \\
\hline Latvia & & & & $\mathrm{x}$ & $\mathrm{x}$ & $\mathrm{x}$ & $\mathrm{x}$ \\
\hline Hungary & & & $\mathrm{x}$ & $\mathrm{x}$ & $\mathrm{x}$ & & $\mathrm{x}$ \\
\hline Costa Rica & & & & $\mathrm{x}$ & $\mathrm{x}$ & & \\
\hline Romania & $\mathrm{x}$ & $\mathrm{x}$ & $\mathrm{x}$ & $\mathrm{x}$ & $\mathrm{x}$ & $\mathrm{x}$ & $\mathrm{x}$ \\
\hline Russia & & $\mathrm{x}$ & $\mathrm{x}$ & $\mathrm{x}$ & $\mathrm{x}$ & $\mathrm{x}$ & $\mathrm{x}$ \\
\hline Saudi Arabia & & & & $\mathrm{x}$ & $\mathrm{x}$ & $\mathrm{x}$ & $\mathrm{x}$ \\
\hline Slovakia & & & & & & & $\mathrm{x}$ \\
\hline Slovenia & & & & & & & $\mathrm{x}$ \\
\hline Turkey & & & & & & $\mathrm{x}$ \\
\hline Ukraine & & & & & & $\mathrm{x}$ \\
\hline
\end{tabular}

Source: Annual reports of central banks, direct inquiries to central banks

\footnotetext{
${ }^{12}$ Indirect measurements of the amount of marks outside Germany (Seitz, 1995; Doyle, 2000) suggest that there are about 80 to 190 billion marks in circulation outside Germany, while analogous measurements for the dollar (Feige, 1996, 1997; Porter and Judson, 1996) speak of an amount of 190 to 290 billion USD in circulation outside the US. Bearing the exchange rate in mind, it follows that 3 to 5 times as many dollars are in circulation outside their mother country than marks.
} 
The availability of the data enables the testing of the initial assumption, which is that there is a connection between the currency substitution index and the share of high value notes in the total value. However before we start off on econometric analysis, it is worth mentioning that we have decided on a very simple rule that assumes that all bills with a denomination of more than $\$ 50$ (according to purchasing power parity) belong to the high denomination group.

In the first equation (Equation 1; Table 5), according to the definition of high denominations and data about currency substitution index, we tested the basic link between the two variables. Thus at the outset we attempted to check the initial hypothesis. The dependent variable of the currency substitution index is denoted LCSIn, the prefix L marking a logarithmic transformation, while the high denominations variable bears the denotation HiDenom. The test was carried out with two dummy variables, one for Romania and the other for Russia. Here it should be emphasised that the dummy variable for Russia excludes only the first three years $(1993,1995,1995)$ from the analysis, while it keeps the other three years (1996-1998) because of the relatively low degree of inflation in these years. Table 4 shows the rates of inflation in Romania and Russia in the period observed, which give justification for the employment of the dummy variables.

Table 4 Rates of inflation in Romania and Russia (in \%)

\begin{tabular}{|l|r|r|r|r|r|r|r|}
\hline & 1992 & 1993 & 1994 & 1995 & 1996 & 1997 & 1998 \\
\hline $\begin{array}{l}\text { Romania } \\
\text { Russia }\end{array}$ & 211 & 255 & 137 & 32 & 39 & 155 & 59 \\
\cline { 2 - 8 } & & 875 & 308 & 197 & 48 & 15 & 28 \\
\hline
\end{tabular}

Source: International Financial Statistics, IMF.

Results of the first equation unequivocally suggest the existence of a significant link and bear out the initial hypothesis. The parameter with the HiDenom variable is significant even in an unrefined (initial) equation at a level lower than $10 \%$, and, which is still more important, has a minus sign in front of it. The link, then, is exactly what was expected - the greater the currency substitution index (greater level of dollarisation) the fewer the banknotes in the local currency with high denominations in circulation. The low R squared need not be commented on, but it should be said that even this kind of R squared is a "sound" magnitude considering the nature of the phenomenon that is being tested. At any event, it will be shown that inclusion of additional explanatory variables will improve the quality of the estimation. Once again we must remark that this is not crucial in this testing. At this degree it was crucial to show the existence of a significant connection between the independent variable (LCSIn) and certain independent variables, the emphasis here being on the independent variable HiDenom.

For the purpose of improving the estimate of the equation, we decided to include two more independent variables that describe the phenomenon under observation. In the first iteration, we included into the equation the variable per capita personal consumption, adjusted by PPP (PrivatCon), and in the second iteration the average value weighted size of the denomination of domestic banknotes adjusted by PPP (AveDenom). Both of these variables are included for the sake of a better description of the denomination structure of local notes. From this point of view we included the AveDenom variable in order to give one more point from the distribution of denominations, and the variable PrivatCon in order to neutralise the effect of the existence of relatively high denominations in countries with a relatively high level of personal consumption.

The results of the regressions performed are shown in Table 5, Equation 2 showing the result after the PrivatCon variable was included, and Equation 3 the comprehensive result after the inclusion of both additional variables. It should be noticed that immediately after the inclusion of the first variable (PrivatCon) the constant member, which in such kind of testing can take on various errors, became significant. The significance of our basic variable deteriorated slightly, but at the same time the newly included variable was proven to be highly significant. The introduction of the AveDenom variable additionally, and essentially 
too, improved the quality of the regression equation. The constant member remained significant, the basic independent variable (HiDenom) became markedly significant, which also goes for the other variables in the equation. Finally the value of $\mathrm{R}$ squared shows that the interpreted variability of the residuals increased by twenty percentage points when the additional independent variables were included.

Table 5 Results of regressions (LCSIn the dependent variable)

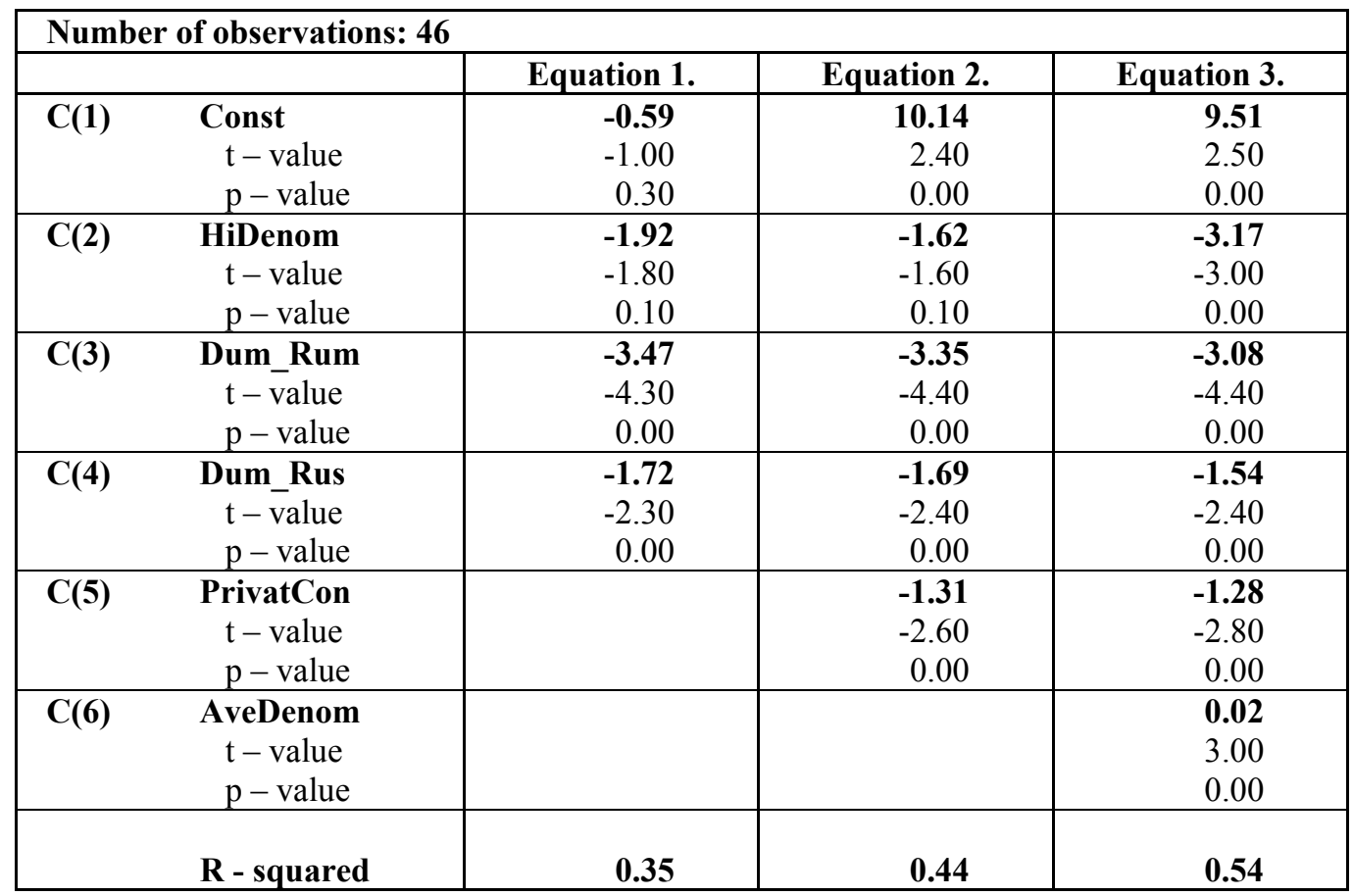

Finally, bearing in mind all the problems with data stated, it is worth recalling that the results obtained need to be treated with caution. They certainly can be of an indicative nature, and in line with this from them one can derive indicative estimates of the amount of foreign cash in Croatia. We have decided to use two methods in order to estimate the amount of foreign cash in Croatia. The first is to substitute Croatian variables into Equation 3, which showed the best fit. The second way is to average over all three estimates, which we consider to be more appropriate due to the high uncertainty of our estimates. In table 6 we present estimates based on all three equations and the corresponding annual averages that will be used in order to derive estimates of UE dynamics in Croatia.

Table 6 Indicative estimates of the amount of foreign cash in Croatia (expressed in USD per capita)

\begin{tabular}{|c|c|c|c|c|}
\hline & According to Eq. 1 & According to Eq. 2 & According to Eq. 3 & Mean \\
\hline 1994 & 82 & 122 & 162 & 122 \\
1995 & 95 & 99 & 125 & 106 \\
1996 & 109 & 111 & 152 & 124 \\
1997 & 144 & 120 & 204 & 156 \\
1998 & 147 & 122 & 185 & 151 \\
1999 & 123 & 118 & 166 & 135 \\
2000 & 149 & 133 & 186 & 156 \\
\hline
\end{tabular}

Source: Authors' estimates 
As can be seen, all our estimates suggest that there has been a tendency for foreign currency in circulation to rise in the post-stabilisation era. A technical explanation of this phenomenon is the fact that in this period the narrow monetary aggregate has risen considerably, but without any essential changes in the denomination structure of the notes which would indicate increased use of kuna in larger transactions and in the UE. An explanation of the persistence of the amount of cash in circulation is given by the theory of network externalities (Feige et al., 2001). According to network externality hypothesis, in a situation without any exogenous shocks it is very hard to drive "entrenched" means of payment out of circulation by another means of payment. Finally, it also worth mentioning that the denomination displacement method actually estimates the amount of foreign cash that is used for the transaction purposes, which means that larger quantities of cash might be in circulation, but are mainly used for the hoarding purposes. This observation is compatible with the phenomenon of the drain of deposits noted during the banking crisis of 1999 (which can be seen in the registered cash flows from the public), which our estimates of the amount of foreign cash in circulation do not tend to indicate.

\section{Monetary methods of estimating the size of the UE}

In the literature, two monetary methods of estimating UE dynamics are familiar. The first approach (sometimes called the Cagan method) is founded on the link between demand for money and the level of tax pressure (Jankov, 1997; Schneider and Enste, 2000). Cagan's method has been improved by Tanzi, who estimated the function of the demand for cash as a medium that is principally used in the UE. Tanzi used different conventional determinations of the demand for money, such as income, interest rates, the development of habits of payment and so on, as control variables. He has also included both direct and indirect tax rates and the level of the national regulations and the complexity of the tax system into the equation, which he assumed to be the main factors that led to working in the UE. The basic form of the equation that Tanzi evaluated is:

$\ln \left(\mathrm{C} / \mathrm{M}_{2}\right)_{\mathrm{t}}=\beta_{0}+\beta_{1} \ln (1+\mathrm{TW})_{\mathrm{t}}+\beta_{2} \ln (\mathrm{WS} / \mathrm{Y})_{\mathrm{t}}+\beta_{3} \ln \mathrm{R}_{\mathrm{t}}+\beta_{4} \ln (\mathrm{Y} / \mathrm{N})+\mathrm{u}_{\mathrm{t}}$

where $\mathrm{C} / \mathrm{M}_{2}$ is the percentage amount of cash in the money supply, TW the measured rate of taxation, modifications to which ought to bring about changes in the UE, WS/Y the share of wages and salaries in the national income, $\mathrm{R}$ the interest rate, or the opportunity cost of keeping cash, and $\mathrm{Y} / \mathrm{N}$ the per capita income. The values of the parameters expected are:

$\beta_{1}>0, \beta_{2}>0, \beta_{3}<0, \beta_{4}>0$

Two steps are needed in order to arrive at estimates of the size of the UE with the Tanzi method. In the first step one has to estimate the surplus in the demand for cash, in other words the amount of the rise in the demand for cash that cannot be explained by traditional demand factors, but can be ascribed to the rise in the tax burden and other governmental constraints. The rise in the demand for cash, of course, is estimated vis-à-vis some base period in which it is assumed that the UE did not exist. In the second step, after the amount of the demand for cash that springs from the UE has been determined, assuming equal income-based velocity of money in the $\mathrm{OE}$ and the UE, the size of the UE as against that of the OE is derived. As can be seen, in each step the UE estimation, several assumptions are made that cannot in fact be proved. This is the main reason for criticisms of Tanzi's method. In addition, the level of tax burden, which is stated in the basic equation as the only determinant of the level of the UE, is just one of a complex of various factors that are hard to quantify.

Gutmann's approach is the second derivation of the Cagan method, although it is sometimes held to be a method of its own. There are no real reasons for this, because the two approaches are actually based on the same idea (Schneider and Enste, 2000). The Guttman approach is a simplification of Cagan's, in which statistical procedures and the effects of other factors are 
taken out, and changes in the proportion of cash in the overall money supply are ascribed only to the dynamics of the UE.

The mathematical parameter $k$, assumed to describe the long-term behaviour of cash needed for the $\mathrm{OE}$, is equivalent to the ratio of cash and deposits in the initial period:

$$
\mathrm{k}=\mathrm{C}_{\mathrm{t}=0} / \mathrm{D}_{\mathrm{t}=0} .
$$

The percentage of cash that is used in the OE in all subsequent periods is derived with the use of the parameter $k$ and the amount of deposit money:

$$
\mathrm{C}_{\mathrm{o}}=\mathrm{kD} \text {. }
$$

In accordance with this, the total money supply consists of deposit money and cash, which is partially used in the OE, and partially in the UE.

$$
\mathrm{M}_{1}=\mathrm{C}_{\mathrm{o}}+\mathrm{C}_{\mathrm{u}}+\mathrm{D} .
$$

The next step makes use of the assumption of the identical velocity of cash used in the UE $\left(\mathrm{C}_{\mathrm{u}}\right)$ and money that is used in the OE $\left(\mathrm{C}_{\mathrm{o}}+\mathrm{D}\right)$. In line with this, the level of the UE in all subsequent periods is estimated as the multiple of the amount of cash used in the UE and the derived speed of the circulation of money in the OE.

Both these methods have certain weaknesses. For example, there is no reason to believe that the velocity of money in the UE and the OE are the same, especially since there are different phenomenal forms of money (cash and deposits). The ratio of cash to deposits may be increased because companies learn to optimise the amount of money in their accounts, in which they are assisted by financial innovations, not because of the rise in the UE. There is no proof that it is only cash that is used in the UE, while the use of deposited money is limited to the OE. If deposit money is really used in the UE, the real level of the UE could be even higher than estimated.

Some of these problems are addressed in the second variant of the monetary approach, the transaction or Feige approach. The main assumption of this is the assumption of the existence of a constant link between the volume of transactions in the economy (cash or non-cash) and the size of GDP (created in both the OE and the UE). However, shifting the problem of measuring the UE to measuring the volume of overall transactions does not actually settle it. Measuring the total volume of transactions is also not very simple, particularly for the cash part of transactions.

Getting into the area of the application of monetary methods to the measurement of the UE in Croatia we meet a number of practical problems. The monetary approach is based on long series of monetary data from which it is possible to derive money demand function and other conclusions about reactions of habits of keeping local cash with respect to changes in the legislative and tax environment. But in Croatia, because of the various shocks that have occurred in the still short post-stabilisation period, like the repatriation of deposits from abroad and the banking crisis of the end of the nineties, it is very difficult to expect a reliable correspondence between monetary variables and variables approximating the level of the regulatory and fiscal burden. Considering the instability of the money demand function in Croatia, which is evident from the different parameters estimated when the estimate is carried over different periods of time (Babić, 2000), statistical properties of the monetary variables do not allow us to use them in estimates of UE dynamics. A few years ago, Jankov (1997) provided a similar conclusion, and because of the properties of the monetary variables we think that in the meantime no substantial changes have occurred from this point of view.

If we were nevertheless to opt for the transaction approach, we would be faced with new problems - the reliability of the size of total transactions. The problem is particularly large for 
cash transactions. Of course, there are indicators of the average life of Croatian banknotes, depending on the denominations. However, so far there has been no research of the average number of transactions that can be carried out with these notes, which makes an estimate of the amount of cash transactions practically impossible.

Because of the problems we have decided to avoid statistical procedures and test out the simple Gutmann approach using Croatian data. This exercise should be taken as an intellectual experiment, and with respect to the estimates obtained, one has to be aware that they are primarily of an indicative nature.

The assumptions from which we started are standard for the Guttman model. We have assumed that deposit money (i.e., the non-cash component of $\mathrm{M}_{1}$ ) is used only in the OE, while cash is used both in the OE and the UE. Additionally, cash used in the OE is a linear function of deposit money. A further assumption relates to the level of UE in the period that we have chosen as the starting period. We have decided to base our estimate on 1995, because this was the year with which a previous study ended (Bićanić, 1997). As the starting level for the UE we have decided to take $25 \%$ of GDP as recorded in the OE, which is found to be an average for the period from 1990 to 1995 by the previous study. Various estimates for the last year in this period oscillate around this level, but the average does not deviate very much. Table 7 shows the dynamic of cash as a percentage of total money and the level of the UE derived on the basis of the assumptions given.

Table 7 Estimates of the size of the UE based on the Gutmann method, with the employment of domestic monetary aggregates.

\begin{tabular}{|l|c|c|c|c|c|c|}
\hline & 1995 & 1996 & 1997 & 1998 & 1999 & 2000 \\
\hline $\mathrm{C}_{1} \mathrm{M}_{1}$ & 0.38 & 0.38 & 0.40 & 0.40 & 0.42 & 0.38 \\
\hline $\mathrm{GDP}_{\mathrm{UE}}$ & $25.0 \%$ & $24.7 \%$ & $29.2 \%$ & $29.8 \%$ & $34.0 \%$ & $25.3 \%$ \\
\hline
\end{tabular}

Although the indicators show a large degree of variability, the method does indicate a rising trend in the UE during the five years for which we have carried out the analysis. The absolute level of the UE in each year can be increased or decreased by changing the assumption about its initial level. The results are of course subject to all the usual criticisms about the use of monetary methods, criticisms that with respect to Croatia are more than usually important. In the continuation we shall devote more attention to criticisms of monetary methods due to the widespread dollarisation and we shall attempt to use the problem of dollarisation constructively for a different approach to evaluating UE dynamics.

Monetary methods for estimating the UE were developed and their use started in advanced countries that are not even remotely subject to the problems of dollarisation to the extent that exists in many countries with a lower level of per capita GDP. However, OECD countries encounter problems of a different kind. Large quantities of their cash circulate abroad, and changes in international cash flows can have a considerable effect on the success of monetary methods of estimating the UE in these countries. Because of all the evidence indicating the importance of the amount of foreign cash in circulation for the UE in dollarised countries, it might be expected that researchers would have put it at the focus of their UE research. Nevertheless, as far as we know, monetary estimates of the UE in dollarised countries are still based on local currency data, and awareness of the problems with monetary methods of measuring the UE that are created by dollarisation is often pushed to the side or relegated to footnotes.

There are many examples to support this contention. For instance, Nenovsky and Hristov (2000), according to the rise in the amount of local cash in circulation, especially high denomination notes, concluded, pursuant to monetary methods, that after the introduction of the currency board in Bulgaria and the stabilisation of prices, the UE rose. They made use of 
the fact that foreign cash co-circulates in the Bulgarian economy to interpret their estimate as the lower limit of the UE. This conclusion however is quite the opposite of the thesis we have put forward, according to which high inflation is one of the important causes of entry into the UE. Through a stabilisation of the economy, this impulse vanishes, which should thus be accompanied by a lower level of UE. Ogunc and Yilmaz (2000) applied the monetary method in a similar way using Turkish data, but warned that in any interpretation of the results in unstable economies one has to be particularly wary. Jankov (1997) shows much more caution interpreting Croatian monetary variables. After a presentation of domestic monetary aggregates in Croatia and of flows of foreign cash through the banking system, he concludes that it is very difficult to infer any conclusions about the dynamics of the UE before 1997 from these figures.

There are several reasons why researchers, the whole time very much aware of the problems that reliance on data about the domestic component of the total cash leads to, have not attempted to include dollarisation into UE research. The first reason is the lack of information about and poor reliability of data about foreign cash in circulation, unlike data domestic monetary data, which are there in ready-made forms in the balance sheets of the monetary institutions. To this we should add the low level of knowledge about the real role of foreign cash in the UE. In brief, it would seem that monetary methods of UE research to date have entailed a resolute avoidance of the obvious simply because the standard exact methods cannot be applied to it.

In our endeavour to estimate Croatian UE dynamics we shall attempt to stick to simple assumptions because we are of the opinion that the very attempt of an estimate based on foreign cash in circulation is a move in the right direction. Firstly, we shall assume that only local currency is used in the OE, while only foreign currency is used in the UE, in the form of cash at that. Further, we shall assume that changes in the ratio of the two components of the GDP, that is the GDP created in the OE and that generated in the UE are in proportion to changes of the ratios of the estimated amount of foreign cash in circulation and the domestic monetary aggregate $\mathrm{M} 1$, as is shown in this identity:

$\left(\mathrm{FCC}_{\mathrm{t}} / \mathrm{M}_{1 \mathrm{t}}\right) /\left(\mathrm{FCC}_{\mathrm{t}-1} / \mathrm{M}_{\mathrm{tt}-1}\right) \equiv\left(\mathrm{BDP}_{\mathrm{UEt}} / \mathrm{BDP}_{\mathrm{OEt}}\right) /\left(\mathrm{BDP}_{\mathrm{UEt}-1} / \mathrm{BDP}_{\mathrm{OEt}-1}\right)$

From this assumption derives the assumption that changes in the income velocity of the circulation of the domestic monetary aggregate $\mathrm{M}_{1}$ and foreign cash are proportional. Of course, foreign cash must be used in many transactions such as the purchase of used residences and cars that could not be considered generators of the UE. In such transactions, most of the taxes to the state are paid, but since the transactional medium is foreign cash, these transactions do nevertheless in a certain way belong in the informal sphere. Since they do not contribute to GDP, they do not affect the income velocity of circulation of foreign cash, and they will not be considered here. The last of these assumptions is the initial level of the UE. In the previous estimate we started off from the level of $25 \%$, which is what we shall keep in this one. Table 8 gives results of an estimate based on estimations of foreign cash in circulation.

Table 8 Estimates of the size of the UE based on estimations of foreign currency in circulation

\begin{tabular}{|l|c|c|c|c|c|c|}
\hline & 1995. & 1996. & 1997. & 1998. & 1999. & 2000. \\
\hline FCC/M $_{1}$ & 0.29 & 0.26 & 0.30 & 0.30 & 0.32 & 0.30 \\
\hline BDP $_{U E}$ & $\mathbf{2 5 . 0 \%}$ & $\mathbf{2 3 . 7 \%}$ & $\mathbf{2 7 . 1 \%}$ & $\mathbf{2 4 . 7 \%}$ & $\mathbf{2 4 . 9 \%}$ & $\mathbf{2 8 . 7 \%}$ \\
\hline
\end{tabular}

Source: $C N B$ and authors' calculations

Although at the inter-year level the estimates show large fluctuations, and the level of the UE falls in a number of years, it is still possible to discern a rising trend. 
We use the electricity consumption method in order to obtain an estimate of UE dynamics from sources independent of money aggregate trends to check the consistency of estimates based on monetary methods. In estimating the UE with the electricity consumption method we shall stick to the assumption on the unitary elasticity of change in the consumption of electricity to changes in the overall $\mathrm{GDP}^{13}$ also used by Kaufmann and Kaliberda (1996). A decision to base this estimate on overall consumption is motivated by the possibility that some of the electricity produced is actually stolen, which is thus recorded within losses. At the end, we shall also adhere to the assumption that the UE came to $25 \%$ of the OE in 1995 .

The method by which the UE is estimated via electricity consumption has been subject to criticisms in its simplest form. First of all, not all economic activities are equally electricityintensive, while some service industries that are easier to conceal or switch into the UE are often labour intensive. Technological advances that increase efficiency reduce the need for electricity, and electricity consumption elasticity compared with changes in GDP can change in some years (Schneider and Enste, 2000). Finally, the weather can impinge crucially in some years. Nevertheless, observation of trends over a longer period of time should cancel out the effect of inter-year temperature oscillations.

Table 9 shows the dynamics of registered real GDP, the consumption of electricity, and an estimate of the dynamics of UE expressed by what percentage it constitutes of the OE, derived according to the consumption of electricity.

Table 9 Estimates of the dynamics of the UE in Croatia using the electricity consumption method.

\begin{tabular}{|l|c|c|c|c|c|c|}
\hline & 1995. & 1996. & 1997. & 1998. & 1999. & 2000. \\
\hline Rate of rise of GDP (OE) & & $5.9 \%$ & $6.8 \%$ & $2.5 \%$ & $-0.4 \%$ & $3.8 \%$ \\
\hline GDP Index (OE) & 100.0 & 105.9 & 113.1 & 115.9 & 115.5 & 119.9 \\
\hline Rate of rise in electricity consumption & & $5.7 \%$ & $6.1 \%$ & $4.4 \%$ & $2.4 \%$ & $1.2 \%$ \\
\hline Total GDP (OE + UE) & 125,0 & 132.2 & 140.2 & 146.4 & 149.9 & 151.7 \\
\hline UE as percentage of OE & $\mathbf{2 5 . 0 \%}$ & $\mathbf{2 4 . 8 \%}$ & $\mathbf{2 4 . 0 \%}$ & $\mathbf{2 6 . 3 \%}$ & $\mathbf{2 9 . 8 \%}$ & $\mathbf{2 6 . 5 \%}$ \\
\hline
\end{tabular}

Source: NSO, Croatian Electricity Industry, authors' calculation

In order to compare the three estimates of the UE in a simple way we have shown them in Figure 1. After a slight fall in 1996, which all methods indicate, from 1997 on there is a divergence in the results in the direction of the trends during some of the years, as there is in the level attained.

\footnotetext{
${ }^{13}$ Figures about electricity consumption can be found on the Web site of Hrvatska elektroprivrede (www.hep.hr). In this estimate we took into consideration total consumption (major consumers, distribution and losses, household consumption).
} 
Figure 1 Estimates of UE dynamics

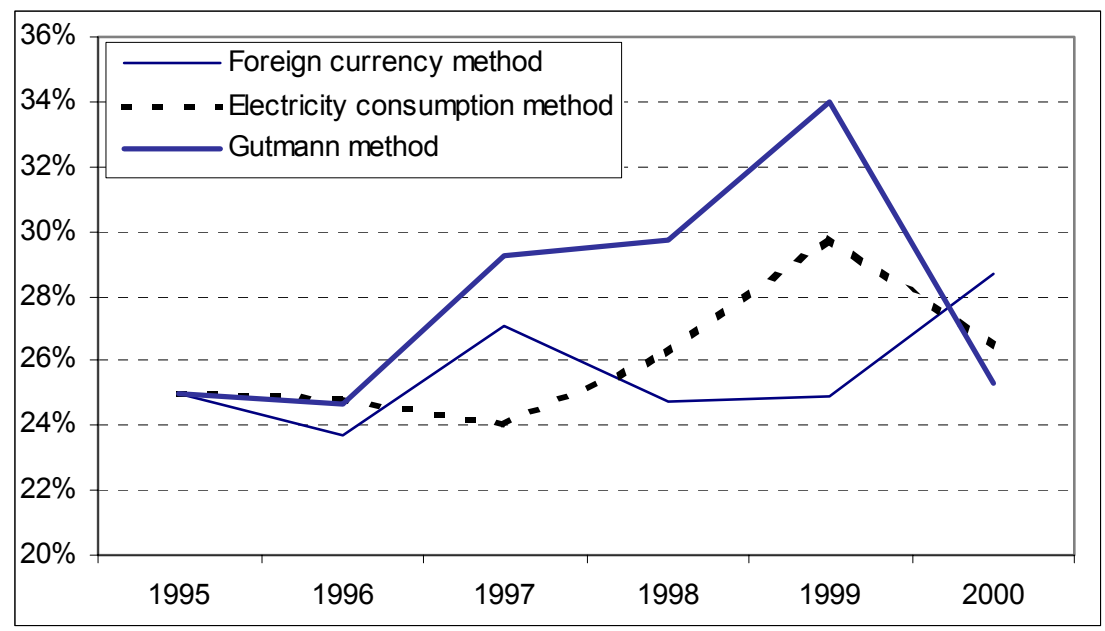

Source: Table 9

The foreign currency method shows the lowest rise in the period observed, but the level of the UE estimated with the use of this method at the end of the given period is the highest of the three estimates. Apart from this, the Gutmann method suggests the highest growth in the UE within the period but the estimate for the end of the period is the lowest. Nevertheless, if the variations between years, which are very high, are ignored, and if we concentrate on the trends, it is clear that the UE, in all methods employed, shows a tendency to rise during the observed period. The observed period is relatively short, but we think the fact that all three UE trends, as estimated by independent methods, indicate a rise is very important.

Figure 2 Estimates of UE dynamics - linear trends

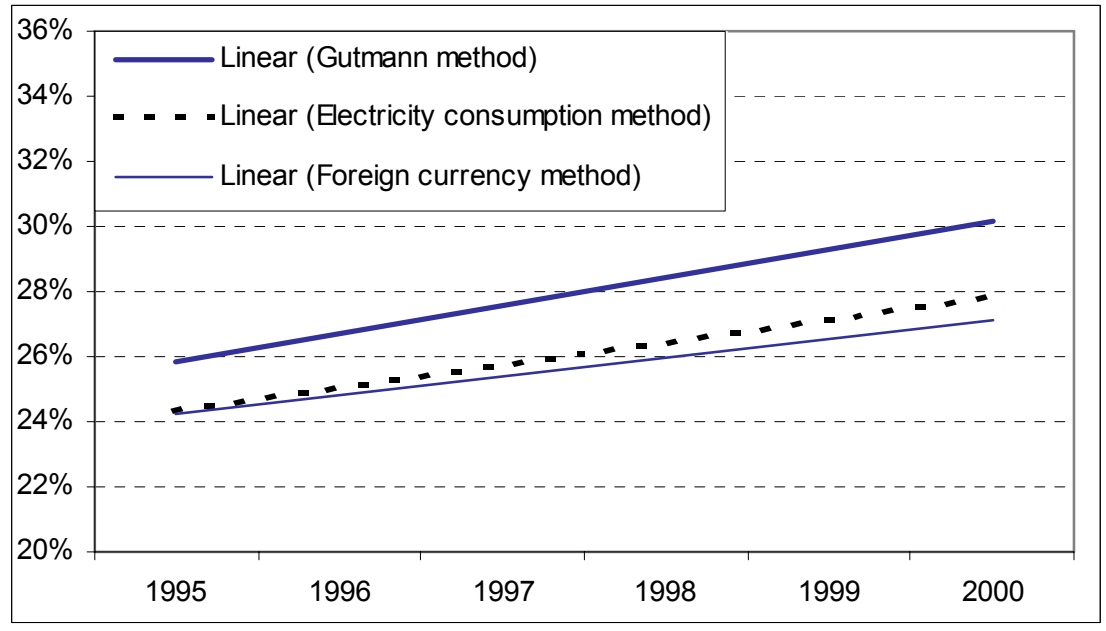

Source: Table 9

The GDP as recorded in the OE rose a cumulative $19.9 \%$ during that period, which comes down to an average annual growth rate of $3.7 \%$. This rate is higher than the rate of growth obtained in EU countries at the same time, but cannot be considered high considering the growth that could be expected when one factors in the base, lower than the GDP of before the transition, and much lower than the GDP of EU countries. Of course, in this period a recession was recorded, one accompanied by the banking crisis, which in one of the years led to a reduction of the GDP recorded in the OE, which accordingly had an effect on the cumulative growth. If the assumption of about a 3 to 5\% rise in the UE in this period is accurate, which is indicated by UE level trends estimated by monetary and electricity 
consumption methods, this would increase the average annual rate of growth in the overall economy by 0.5 to $1 \%$. If these estimates are not in line with real trends, the rate of growth of overall GDP would have to be lower than the rate of the growth of the GDP recorded in the OE.

\section{Conclusion}

In this paper we have attempted to bring together UE literature and dollarisation, considering that this connection is actually a missing link, and is capable of enhancing the quality of research in both areas. We are aware that our estimates are of an indicative nature only and subject to criticism, and hence our intention was more to draw attention to the importance of dollarisation for UE research than to give its final estimates. However, the measurement of unofficial dollarisation is still embryonic, and our estimate relies on first attempts at measurement of the geographical distribution of the foreign cash in circulation. For this reason we expect that the link that we have suggested will in the future lead to more qualitative answers, and several facts make this probable. First of all, the introduction of the euro was a unique chance to measure the geographical distribution of the mark, about which there has been very little real knowledge to date. Further, the introduction of cash euros, especially the highest denomination, of EUR 500 (which according to the current exchange rate is five times the value of the highest denomination dollar bill) could represent a challenge to the dollar as a co-circulating currency in universal terms. The measurement of the process of the replacement of the cash dollar by the euro, if and when this occurs, could provide valuable information about transaction costs of using cash in the UE, the dynamics of the actual process of unofficial dollarisation and network externalities that arise during the process.

At the end we should say that we have used three methods (relatively independent of each other) for the estimate of UE dynamics. The first is based on the ratio between local cash and deposits, the second on the estimates of foreign cash in circulation, and the third on electricity consumption. It is interesting that the three independent methods, if the trends are observed, give similar results. This correlation does not necessarily mean that the results are accurate, but does nevertheless give rise to hope that the whole of the exercise is useful. 


\section{LITERATURE:}

BABIĆ, A., 2000. The Monthly Transaction Money Demand in Croatia, Croatian National Bank Working Papers, W-5, September 2000.

BIĆANIĆ, I., 1997. Mjerenje veličina i promjena neslužbanog gospodarstva, Financijska praksa, 21(1-2), 15-29.

CALVO, G.A. and VÉGH, C. A., 1992. Currency Substitution in Developing Countries - An Introduction, IMF Working Paper WP/92/40, International Monetary Fund, Washington DC.

DOYLE, B. M., 2000. Here, dollars, dollars ... Estimating currency demand and worldwide currency substitution, International Finance Discussion Paper No. 657, Board of Governors of the Federal Reserve System, Washington, DC.

FEIGE, E. L., FAULEND, M., ŠONJE, V. and ŠOŠIĆ, V., 2001. Currency Substitution, Unofficial Dollarization and Estimates of Foreign Currency Held Abroad: The Case of Croatia, In: Financial Vulnerability and the Exchange Rate Regime, ed. M. Blejer and M. Škreb. Cambridge, MA; London: MIT Press (in print).

FEIGE, E. L., 1990. Defining and estimating underground and informal economies: The new institutional economics approach, World Development Vol. 18, No. 7; July 1990.

FEIGE, E. L., 1996. Overseas holdings of U.S. Currency and the underground economy, In: S. Pozo (ed), Exploring the Underground Economy, W.E Upjohn Institute for Employment Research.

FEIGE, E. L., 1997. Revised estimates of the size of the U.S. underground economy: The implications of US currency held abroad, In: Owen Lippert and Michael Walker (ed), The Underground Economy: Global Evidence of its Size and Impact, Fraser Institute.

FEIST, H., 2001. The Enlargement of the European Union and the Redistribution of Seigniorage Wealth, Kyklos, Vol. 54 - Fasc. 4, 2001.

GADDY, C. and ICKES, B. W., 1998. To restructure or not to restructure: Informal activities and enterprise behavior in transition, (ms).

IMF, 2001. Financial system abuse, financial crime and money laundering, Background Paper, prepared by the Monetary and Exchange Affairs and Policy Development and Review Departments.

JANKOV, LJ., 1997. Monetaristički oblik neslužbenog gospodarstva, Financijska praksa, 21(1-2)157-167.

KAUFMANN, D. and KALIBERDA, A., 1996. Integrating the unofficial economy into the dynamics of post-socialist economies: A framework of analysis and evidence, World Bank Working Paper, No. 1691, World Bank, Washington.

NENOVSKY, N. and HRISTOV, K., 2000. Currency circulation after currency board introduction in Bulgaria (Transactions demand, hoarding, shadow economy), Bulgarian National Bank Discussion Paper, DP13/2000.

OGUNC, F. and YILMAZ, G., 2000. Estimating the underground economy in Turkey, The Central Bank of the Republic of Turkey, Research Department, Discussion Paper, September 2000.

PORTER, R. and JUDSON, R., 1996. The location of US currency: How much is abroad?, Federal Reserve Bulletin, October 1996.

ROGOFF, K., 1998. Blessing or curse? Foreign and underground demand for euro notes, Economic Policy, April 1998.

SEITZ, F., 1995. The circulation of Deutsche mark abroad, Discussion Paper 1/95, Economic Research Group of the Deutsche Bundesbank, Frankfurt am Main, Federal Republic of Germany.

SPRENKLE, C., 1993. The case of missing money, Journal of Economic Perspectives. 7(4) WORLD BANK, World Development Indicators, various years, Washington D.C. 


\section{INSTITUTE OF PUBLIC FINANCE - OCCASIONAL PAPER SERIES}

No. 1 State Intervention for Growth Promotion in Market Economies. Marina Kesner Škreb, January 1997

No. 2 Estimate of Revenues from the Value Added Tax in the Republic of Croatia. Danijela Kuliš and Žarko Miljenović, October 1997

No. 3 The Unofficial Economy in Croatia: Causes, Size and Consequences. Ivo Bićanić and Katarina Ott, November 1997

No. 4 Price Effects of VAT Introduction in Croatia. Martina Dalić, December 1997

No. 5 Tax Administration Reform in Transition: The Case of Croatia. Katarina Ott, April 1998

No. 6 The Present Sate of the Croatian Public Debt. Zoran Bubaš, December 1998

No. 7 Public Investment in Croatia. Katarina Ott and Anto Bajo, March 1999

No. 8 Welfare Policy and Social Transfers in Croatia. Predrag Bejaković and Alastair McAuley, July 1999

No. 9 Is Unofficial Economy a Source of Corruption? Vedran Šošić and Michael Faulend, November 1999

No.10 Banking Sector Problems: Causes, Resolutions and Consequences. Ljubinko Jankov, March 2000

No.11 Toward a Long-Term Strategy of Economic Development of Croatia: Where to Begin, What to Do, and How to Do It?, Dubravko Mihaljek, June 2001

No.12 The Underground Economy in Croatia. Katarina Ott, March 2002

No.13 An Estimate of the Extent of Tax Evasion in Croatia. Sanja Madžarević Šjujster, April 2002

No.14 Opportunism, Institutions and Moral Costs: The Socio-Cultural Dimension of the Underground Economy In Croatia 1995-1999. Aleksandar Štulhofer and Ivan Rimac, April 2002

No.15 Dollarisation and the Underground Economy: Accidental Partners? Vedran Šošić and Michael Faulend, April 2002 